head-pressure relatively to the earth would be about four pounds per square foot. Light winds, sometimes following, sometimes resisting, the train, caused some variations which were allowed for in computations.

It is to be noted that a plane surface would have given a higher resistance, by at least 50 per cent., than was recorded by the cup-shaped vane.

R. H. T.

\section{TRIVALENT CARBON.}

IN the Journal of the American Chemical Society for November appeared an article of very unusual interest. By the action of silver, mercury or zinc on triphenylchlormethane Dr. M. Gomberg has obtained a new hydrocarbon, triphenyl-methyl, $\left(\mathrm{C}_{6} \mathrm{H}_{5}\right)_{3} \mathrm{C}$. For some reason, perhaps because of space relations involved, two molecules of this hydrocarbon do not unite to form hexaphenylethane, $\left(\mathrm{C}_{6} \mathrm{H}_{5}\right)_{3} \mathrm{C}-\mathrm{C}\left(\mathrm{C}_{6} \mathrm{H}_{5}\right)_{3}$, as would be expected. The new body is the only one among the seventy thousand or more compounds of carbon, which contains an odd number of atoms of odd valence. The compound furnishes the first opportunity of studying the properties of a substance containing a carbon atom that is almost certainly trivalent. From this standpoint, as well as others, the discovery possesses a great theoretical interest. Especially the properties of triphenyl methyl in its rapid absorption of oxygen furnish a practically complete refutation of the view that benzene, ethylene and similar compounds contain trivalent carbon.

W. A. N.

\section{COLUMBIA UNIVERSITY.}

THE trustees of Columbia University have authorized the publication of the following statement drawn up by President Low:

The problem of Columbia University can now be defined, for the first time since, in 1892 , it was determined to move to Morningside Heights.

Cost of land and development at Morningside Heights, ...................... \$6,516,300 17 Improvements at College of Physicians and Surgeons, ................................ 879,68843

$\$ 7,395,98860$

Interest to June 30, 1900, 586,51992
Of this large sum the University has succeeded in paying, mostly out of gifts and legacies, $\$ 4,250,000$. Of its outstanding debt the sum of $\$ 750,000$ is provided for. It still owes $\$ 3,000,000$ that is not provided for; upon which the annual interest payable is $\$ 98,500$.

Careful computations justify the undersigned in saying that eight years from now the University will be able, by the increase of income from its fees and endowments to care for its floating debt without embarrassment to its educational work. The falling-in of contingent interests already definitely established may hasten this result importantly. Experience also demonstrates that the endowments of the University are likely to be constantly increased by gift and legacy year by year.

The problem of the University, therefore, is to conduct its educational work for a period of eight years without curtailment by reason of the interest to be paid in the meanwhile on its outstanding debt, say $\$ 100,000$ a year.

For the academic year ending June 30, 1897, the last year at the 49 th street site, the University had a deficiency on its current educational account, disregarding interest, of $\$ 48,260$. For the coming açademic year, 1901-1902, the estimates for the Budget already made show that the ordinary income of the University next year will pay all of its current expenses except the interest on its outstanding debt.

If our interest payable can be taken care of for eight years, the problem of the University growing out of its removal to the new site will be solved.

From the purely business point of view, the operations of the University have been already justified. Its plant has been increased in value, after deducting the proceeds of its old buildings, by more than $\$ 6,250,000$, taking its new site at cost. If the new site be taken at its present market value, the increase in the value of the University's plant would be not less than $\$ 8,000,000$. The debt incurred in producing these results, still remaining unprovided for, is only $\$ 3,000,000$. In addition, University Hall is now being enlarged by gift; and Earl Hall is about to be erected, also by gift. In the same interval, the trust funds of the University have been increased by $\$ 1,250,-$ 